\title{
Association of pregnancy per artificial insemination with gonadotropin- releasing hormone and human chorionic gonadotropin administered during the luteal phase after artificial insemination in dairy cows: A meta-analysis
}

\author{
M. Besbaci, ${ }^{1,2 *}$ ๑ A. Abdelli, ${ }^{3}$ () J. J. Minviel, ${ }^{4,5}$ I. Belabdi, ${ }^{1}$ R. Kaidi, ${ }^{1}$ and D. Raboisson ${ }^{4}(\mathbb{0}$ \\ ${ }_{1}^{1}$ Laboratory of Biotechnology in Animal Reproduction, Institute of Veterinary Sciences, University of Blida 1, 09,000, Blida, Algeria \\ ${ }^{2}$ High National School Veterinary El Harrach, Algers, 16,000, Algeria \\ ${ }^{3}$ Department of Agricultural Sciences, University of Bouira, 10,000, Bouira, Algeria \\ ${ }^{4} \mathrm{IHAP}$, Université de Toulouse, INRA, ENVT, Toulouse, France \\ ${ }^{5}$ Université Clermont Auvergne, INRA, Vetagro Sup, UMR Herbivores, 63122, Saint-Genès-Champanelle, France
}

\begin{abstract}
One strategy for improving fertility in cattle is administration of GnRH or human chorionic gonadotropin (hCG) during the luteal phase, which increases progesterone (P4) secretion and delays luteolysis. To provide an overview of how $\mathrm{GnRH}$ or hCG treatment between 4 and $15 \mathrm{~d}$ after artificial insemination (AI) improves pregnancy per $\mathrm{AI}(\mathrm{P} / \mathrm{AI})$ in cows, a metaanalysis was performed on 107 different trials from 52 publications. Data from 18,082 treated cows and 18,385 untreated controls were meta-analyzed. The meta-analysis explained the relative risk for $\mathrm{P} / \mathrm{AI}$ with $\mathrm{GnRH}$ or hCG treatment under various circumstances. The results did not show any difference in $\mathrm{P} / \mathrm{AI}$ between cows treated with hCG and cows treated with GnRH. Compared with no treatment, treatment with GnRH or hCG improved the chances of $\mathrm{P} / \mathrm{AI}$ in cows with very poor $(<30 \%)$ and poor (30.1 to $45 \%)$ fertility, whereas treatment did not benefit cows with very good fertility (>60.1\%). Moreover, treatment with GnRH and hCG improved the chances of $\mathrm{P} / \mathrm{AI}$ in primiparous cows. The improvement was much better in primiparous cows with very low fertility. Treatment with buserelin at a dose above $10 \mu \mathrm{g}$ and with $\mathrm{hCG}$ at a dose above 2,500 IU was associated with increased chances of P/AI compared with lower doses. Treatment with GnRH 10 $\mathrm{d}$ after AI was also associated with increased chances of P/AI compared with earlier treatment. The present meta-analysis showed that the use of $\mathrm{GnRH}$ and $\mathrm{hCG}$ after AI should be focused on cows expected to have low or moderate fertility. Day and dose of treatment have to be considered as well.
\end{abstract}

Received February 6, 2019.

Accepted August 20, 2019.

*Corresponding author: besbaci@univ-blida.dz
Key words: human chorionic gonadotropin, gonadotropin-releasing hormone, artificial insemination, cow

\section{INTRODUCTION}

A general belief across both the scientific and commercial dairy communities is the antagonistic association between milk production and reproductive performance of dairy cows (Bello et al., 2012). Low fertility of dairy cows is a big challenge for the industry (Lucy, 2001); however, the combination of improvements in both reproductive management and genetics has greatly improved reproductive performance (Carvalho et al., 2018). Progesterone (P4) insufficiency has been reported to be associated with decreased pregnancy per AI (P/AI), abnormally early embryo development, and reduced signaling for the maternal recognition of pregnancy (Mann and Lamming, 2001; Spencer and Hansen, 2015). Peripheral P4 concentrations are the net result of secretion and metabolism. Increased P4 metabolism by the liver has been hypothesized to cause the decreased P4 concentration in peripheral blood during the estrous cycle in lactating dairy cows (Wiltbank et al., 2006). Progesterone induces secretory changes in the endometrium and is essential for successful implantation of the embryo. It also modulates the immune response of cows to prevent rejection of the embryo and inhibits uterine contractions. All of these changes fail to occur if $\mathrm{P} 4$ is not produced at a sufficient concentration (1 to $2 \mathrm{ng} / \mathrm{mL}$ on d 5 of estrous cycle; Starbuck et al., 2001), whereas a high P4 concentration favors embryonic development and higher P/AI (Lonergan, 2011).

Many studies tried to increase the $\mathrm{P} 4$ concentration in the blood to improve $\mathrm{P} / \mathrm{AI}$ in dairy cows (Nascimento et al., 2013; Mendonça et al., 2017; Niles et al., 2019). The administration of GnRH, GnRH agonists or hCG at specific times after AI stimulates corpus luteum (CL) function by inducing accessory CL forma- 
tion. Treatment with these hormones increases the P4 concentration and reduces estradiol production with a consequent positive effect on embryonic survival (Thatcher et al., 2003). These studies failed to deliver a clear consensus on the therapeutic benefits of such treatments. Some reported a beneficial treatment effect of human chorionic gonadotropin (hCG) and $\mathrm{GnRH}$ after $\mathrm{AI}$ on $\mathrm{P} / \mathrm{AI}$, whereas others showed no benefit or even a reduction in $\mathrm{P} / \mathrm{AI}$. Two studies (Peters et al., 2000; Nascimento et al., 2013) have attempted to sum up factors that affect the efficacy of treatment with GnRH and hCG after AI. A first meta-analysis focused on GnRH injected on d 11 to 14 after AI (Peters et al., 2000). A second meta-analysis was performed in the 2010s and focused on hCG administered to dairy cows on d 5 after AI (Nascimento et al., 2013). The meta-analyses included 14 and 10 studies, respectively. The first (Peters et al., 2000) confirmed that the efficacy of GnRH administration between d 11 and 14 after AI was not consistent among the studies. Part of this variation may be explained by differences in study protocol, particularly the method and timing of the pregnancy diagnosis. These results suggest a need for further research to identify factors at the cow or farm level for use of GnRH after AI to improve dairy cow fertility. The second meta-analysis confirmed that hCG administration at d 5 after AI considerably improved pregnancy in primiparous cows but not in multiparous cows. An update of these previous works, including a broader approach, appeared necessary. The objective of this study was to analyze the association of GnRH and hCG treatments, administered 5 to $14 \mathrm{~d}$ after AI, with $\mathrm{P} / \mathrm{AI}$ in dairy cows and to focus on factors that influence this relationship. We hypothesized that a metaanalysis can identify factors affecting the efficiency of GnRH and hCG treatment after AI and consolidating the estimate of the treatment response are possible with a meta-analysis.

\section{MATERIALS AND METHODS}

\section{Literature Search}

Publications comparing hCG-treated or GnRH-treated cows to nontreated control cows were selected from the English-language literature through June 2019. The literature search was conducted in PubMed (http:// www.ncbi.nlm.nih.gov/pubmed), Science Direct (http: //www.sciencedirect.com), and Google Scholar (http: //scholar.google.com). The key words that were used separately or in different combinations for the search were cow, cattle, hCG, GnRH, after, post, AI, embryo, mortality, loss, fertility, pregnancy, and rate. All of the publications that were referenced by at least one of the publications that were identified in the previous step were also included. Duplicate papers were excluded, and screening was conducted to determine whether the final number of articles qualified for a meta-analysis (Figure 1).

\section{Inclusion and Exclusion Criteria}

The papers retained for the analysis had (1) to record the P/AI, (2) to follow a control-case protocol with randomization to allocate treatment, (3) to include a treatment with a single injection of GnRH or hCG during the luteal phase (between 4 and $15 \mathrm{~d}$ after $\mathrm{AI}$ ), and (4) to be carried out on dairy cows. Based on these criteria, 52 papers (107 trials) were included (Supplemental Table S1; https://doi.org/10.3168/jds.2019 -16439). The collective results represented 36,464 cows: 18,082 cows treated with $\mathrm{GnRH}$ or hCG and 18,385 untreated control cows. Of these 52 publications, 33 (57 trials) were conducted with $\mathrm{GnRH}$ (21,825 cows, with 10,845 treated cows and 10,980 untreated control cows). Twenty-nine publications (50 trials) were conducted with hCG (14,642 cows, with 7,237 treated cows and 7,405 untreated controls). Ten out of the 52 included both GnRH and hCG treatments (double counted in the 33 and 29 publications). All of these papers were published between 1982 and 2019, and there was no restriction on the publication data. Similarly, there was no restriction on the country where the study was conducted.

\section{Data Extraction and Classification of Studies Analysis}

Data extracted from publications included the number of treated and untreated (control) cows, P/AI, repeat breeders, the nature of the treatment after AI (hCG or $\mathrm{GnRH}$ ), the day of treatment (after AI), the dose of treatment, the molecule of $\mathrm{GnRH}$, the cow parity, the use of a synchronization protocol, the number of days after AI of the pregnancy diagnosis, the method of the pregnancy diagnosis, and the season. Details of the extracted classes are reported in Table 1 . In brief, the moderator (i.e., variable) day of treatment was transformed into a categorical moderator with thresholds of 5 and $10 \mathrm{~d}$ for hCG and GnRH, respectively. The day of treatment was not specified in 30 trials, and the average was taken. The dose of hormone was also categorized for hCG and GnRH (buserelin only; only one dose was observed for the gonadorelin). The thresholds that were used for the moderator day of treatment and dose of hormone were defined by the authors' expertise or based on previous publications for instance for the number of days after AI GnRH has been injected (Pe- 


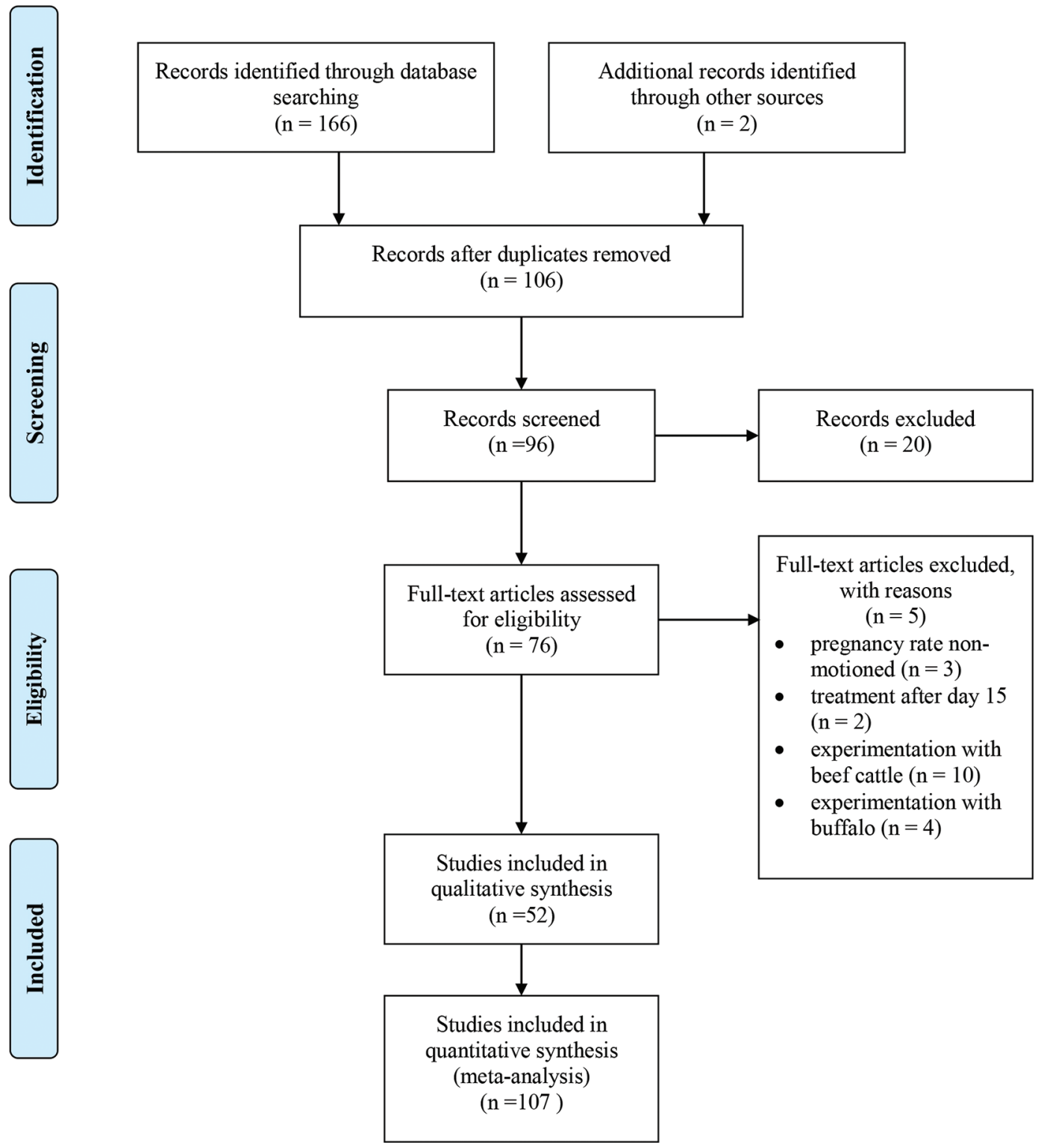

Figure 1. Preferred reporting items for systematic reviews and meta-analysis (PRISMA) study flow diagram of the manuscript selection process.

ters et al., 2000; Nascimento et al., 2013). The molecule of the hormone was also retained as a moderator for GnRH (buserelin or gonadorelin). The thresholds used to classify the fertility (very good, good, poor, and very poor) were obtained (Table 1) from Yan et al. (2016).

\section{Statistical Analysis}

All meta-analyses were conducted using the metafor package (version 2.0-0) of $\mathrm{R}$ (version 3.5.1; $\mathrm{R}$ Foundation for Statistical Computing, Vienna, Austria). Random-effects models were first used to estimate the log-effect size, its $95 \%$ confidence interval, and the statistical significance. Statistical heterogeneity was assessed using the Cochran Q statistic and the $I^{2}$ statistic of the proportion of total variation due to heterogeneity (Higgins and Thompson, 2002). For response variables with high $I^{2}$, uni- or multivariable meta-regressions were then performed to explore the sources of heterogeneity and reduce them. Meta-analysis is a statistical method used to aggregate, synthesize, and compare the results from several related studies in a systematic way. Briefly, the meta-analysis includes (1) a check for study selection bias, (2) performance of a meta-regressiona regression applied to metadata, each variable being called a moderator, and (3) a search for outlier 
contributors (a study included in the regression that leads the results). The meta-regression is consequently a step of the meta-analysis. The meta-regression was conducted by regressing the observed effect sizes on one or multiple study characteristics (moderators). We used the following moderators: fertility, parity, repeat breeders, nature of treatment after ( $\mathrm{hCG}$ or $\mathrm{GnRH})$, day of treatment, dose of treatment, molecule of $\mathrm{GnRH}$, use of a synchronization protocol, number of days after AI for the pregnancy diagnosis, method of pregnancy diagnosis, and the season (Table 1). The variable publication was kept as a random effect, and it was estimated as combined relative risk (RR) and its $95 \%$ confidence interval. A sensitivity analysis was performed to identify outliers. Publication bias was assessed by performing Egger's test (Egger et al., 1997), a regression test for funnel plot asymmetry and inspection of the associated funnel plots. Outliers were also identified by conducting an influential case diagnostic [i.e., DFFITS value, Cook's distances, covariance ratios, estimates of $\tau^{2}$, and test statistics for (residual) heterogeneity].

\section{RESULTS}

The funnel plot did not suggest a bias of publication (Figure 2). Table 2 summarizes the univariable meta-regressions. The meta-regressions performed by subpopulations are provided in Supplemental Table S2

Table 1. Descriptive statistics of the pregnancy per artificial insemination (P/AI) for the moderators used in the meta-regression

\begin{tabular}{|c|c|c|c|c|}
\hline \multirow[b]{2}{*}{ Moderator } & \multirow[b]{2}{*}{ Class } & \multirow[b]{2}{*}{$\begin{array}{l}\text { No. of } \\
\text { trials }\end{array}$} & \multicolumn{2}{|c|}{$\mathrm{P} / \mathrm{AI}$} \\
\hline & & & $\begin{array}{l}\text { Treatment }^{1} \\
{[\% \text { (no./total) }]}\end{array}$ & $\begin{array}{c}\text { Control }^{2} \\
{[\%(\text { no. } / \text { total })]}\end{array}$ \\
\hline \multirow[t]{2}{*}{ Treatment } & $\mathrm{GnRH}$ & 57 & $45.85(4,973 / 10,845)$ & $43.81(4,811 / 10,980)$ \\
\hline & $\mathrm{hCG}^{3}$ & 50 & $41.97(3,038 / 7,237)$ & $39.06(2,893 / 7,405)$ \\
\hline \multirow[t]{3}{*}{ Parity } & Nulliparous & 4 & $49.24(195 / 396)$ & $47.08(178 / 378)$ \\
\hline & Primiparous & 11 & $40.12(634 / 1,580)$ & $35.18(551 / 1,566)$ \\
\hline & Multiparous & 22 & $30.78(1,183 / 3,843)$ & $30.54(1,191 / 3,899)$ \\
\hline \multirow[t]{5}{*}{ Use of synchronization } & No (spontaneous estrus) & 12 & $58.17(1,149 / 1,975)$ & $55.67(1,094 / 1,965)$ \\
\hline & $\mathrm{GnRH} / \mathrm{PGF}_{2 \alpha}$ & 45 & $35.20(2,745 / 7,797)$ & $33.20(2,598 / 7,823)$ \\
\hline & $\mathrm{PGF}_{2 \alpha}$ only & 9 & $48.70(566 / 1,162)$ & $40.48(455 / 1,124)$ \\
\hline & Progesterone & 9 & $38.68(610 / 1,577)$ & $39.96(625 / 1,564)$ \\
\hline & Mix (different protocol) & 9 & $51.17(1,177 / 2,300)$ & $50.70(1,230 / 2,426)$ \\
\hline \multirow[t]{4}{*}{ Season } & No (all year long) & 23 & $39.08(1,542 / 3,945)$ & $36.57(1,480 / 4,046)$ \\
\hline & Cold (winter) & 12 & $57.70(1,172 / 2,031)$ & $56.76(1,246 / 2,195)$ \\
\hline & Hot (summer) & 14 & $27.44(614 / 2,237)$ & $26.42(564 / 2,134)$ \\
\hline & Mix (different season) & 22 & $48.68(2,050 / 4,211)$ & $44.55(1,869 / 4,195)$ \\
\hline \multirow{3}{*}{$\begin{array}{l}\text { Method of pregnancy } \\
\text { diagnosis }\end{array}$} & Rectal palpation & 49 & $51.04(3,379 / 6,620)$ & $47.80(3,290 / 6,882)$ \\
\hline & Ultrasonography & 31 & $41.18(2,421 / 5,878)$ & $39.60(2,332 / 5,888)$ \\
\hline & Both & 16 & $39.02(1,600 / 4,100)$ & $37.08(1,510 / 4,072)$ \\
\hline \multirow[t]{3}{*}{ Week of pregnancy diagnosis } & $\leq 4 \mathrm{wk}$ & 15 & $36.84(948 / 2,573)$ & $34.19(887 / 2,594)$ \\
\hline & $\overline{4}$ to $\leq 6 \mathrm{wk}$ & 34 & $42.83(2,816 / 6,574)$ & $41.83(2,773 / 6,629)$ \\
\hline & $>6 \mathrm{wk}$ & 33 & $53.07(2,765 / 5,210)$ & $49.61(2,682 / 5,406)$ \\
\hline \multirow[t]{2}{*}{ Repeat breeders } & Yes & 17 & $40.25(349 / 867)$ & $37.15(327 / 880)$ \\
\hline & No & 90 & $44.50(7,662 / 17,215)$ & $42.14(7,377 / 17,505)$ \\
\hline \multirow[t]{4}{*}{ Fertility } & Very poor $(<30 \%)$ & 31 & $27.14(1,269 / 4,675)$ & $23.79(1,113 / 4,677)$ \\
\hline & Poor $(30.1$ to $45 \%)$ & 39 & $40.34(2,382 / 5,904)$ & $36.87(2,208 / 5,987)$ \\
\hline & Good ( 45.1 to $60 \%)$ & 26 & $56.13(2,725 / 4,854)$ & $53.02(2,663 / 5,022)$ \\
\hline & Very good $(>60.1 \%)$ & 11 & $61.72(1,635 / 2,649)$ & $63.72(1,720 / 2,699)$ \\
\hline \multirow[t]{2}{*}{ Day of treatment with hCG } & $\leq 5 \mathrm{~d}$ & 26 & $42.02(1,543 / 3,672)$ & $37.97(1,439 / 3,789)$ \\
\hline & $>5 \mathrm{~d}$ & 24 & $41.93(1,495 / 3,565)$ & $40.21(1,454 / 3,616)$ \\
\hline \multirow[t]{2}{*}{ Day of treatment with $\mathrm{GnRH}$} & $\leq 10 \mathrm{~d}$ & 29 & $41.14(2,362 / 5,741)$ & $40.45(2,372 / 5,864)$ \\
\hline & $>10 \mathrm{~d}$ & 28 & $51.15(2,611 / 5,104)$ & $47.67(2,439 / 5,116)$ \\
\hline \multirow[t]{3}{*}{ Dose of treatment with $\mathrm{hCG}$} & $\leq 1,500 \mathrm{IU}$ & 17 & $51.55(794 / 1,540)$ & $45.81(734 / 1,602)$ \\
\hline & $>1,500$ and $\leq 2,500 \mathrm{IU}$ & 12 & $40.62(804 / 1,979)$ & $42.54(847 / 1,991)$ \\
\hline & $>2,500 \mathrm{IU}$ & 20 & $39.43(1,427 / 3,619)$ & $34.59(1,284 / 3,711)$ \\
\hline \multirow{3}{*}{$\begin{array}{l}\text { Dose of treatment with } \mathrm{GnRH} \\
\text { (buserelin only) }\end{array}$} & $<10 \mu \mathrm{g}$ & 4 & $60.54(554 / 915)$ & $63.41(598 / 943)$ \\
\hline & $\geq 10$ and $\leq 10.5 \mu \mathrm{g}$ & 17 & $60.90(2,572 / 4,223)$ & $57.14(2,454 / 4,294)$ \\
\hline & $\overline{\geq} 12 \mu \mathrm{g}$ & 5 & $59.02(121 / 205)$ & $48.94(116 / 237)$ \\
\hline \multirow[t]{3}{*}{ Molecule of $\mathrm{GnRH}$} & Buserelin & 26 & $60.77(3,247 / 5,343)$ & $57.87(3,168 / 5,474)$ \\
\hline & Gonadorelin & 27 & $30.90(1,655 / 5,355)$ & $29.78(1,596 / 5,359)$ \\
\hline & Lecirelin & 3 & $46.71(64 / 137)$ & $32.59(44 / 135)$ \\
\hline
\end{tabular}

${ }^{1}$ Treatment percentage of cows pregnant to $\mathrm{AI}(\mathrm{P} / \mathrm{AI})$.

${ }^{2}$ Control percentage of cows pregnant to $\mathrm{AI}(\mathrm{P} / \mathrm{AI})$.

${ }^{3} \mathrm{hCG}=$ human chorionic gonadotropin. 
Table 2. Results of the univariate meta-regressions

\begin{tabular}{|c|c|c|c|c|c|c|c|}
\hline $\begin{array}{l}\text { Model } \\
\text { no. }\end{array}$ & Moderator & Class & $\begin{array}{c}\text { Estimate } \\
\text { (SE) }\end{array}$ & $\begin{array}{l}\text { Risk } \\
\text { ratio }\end{array}$ & $95 \% \mathrm{CI}$ & $P$-value & $I^{2} \%$ \\
\hline 1 & No moderator & Intercept & $0.07(0.01)$ & 1.07 & $1.03-1.11$ & 0.0002 & 45 \\
\hline \multirow[t]{2}{*}{2} & Intercept & & $0.06(0.02)$ & 1.06 & $1.01-1.11$ & 0.01 & 45 \\
\hline & & $\mathrm{hCG}^{1}$ & & 1.02 & $0.96-1.09$ & 0.85 & \\
\hline \multirow[t]{2}{*}{3} & Intercept & & $0.16(0.04)$ & 1.17 & $1.07-1.28$ & 0.0003 & 39 \\
\hline & Fertility & Very poor & Referent & & & & \\
\hline \multirow[t]{4}{*}{4} & Intercept & & $0.13(0.04)$ & 1.13 & $1.04-1.24$ & 0.002 & 42 \\
\hline & Parity & Primiparous & Referent & & & & \\
\hline & & Nulliparous & $-0.09(0.08)$ & 0.91 & $0.77-1.06$ & 0.23 & \\
\hline & & Multiparous & $-0.09(0.05)$ & 0.91 & $0.81-1.01$ & 0.09 & \\
\hline \multirow[t]{2}{*}{5} & Intercept & & $0.08(0.02)$ & 1.08 & $1.02-1.15$ & 0.005 & 41 \\
\hline & Dose of $\mathrm{GnRH}$ & $\geq 10$ and $\leq 10.5 \mu \mathrm{g}$ & Referent & & & & \\
\hline \multirow[t]{3}{*}{7} & Intercept & & $0.06(0.02)$ & 1.06 & $1.01-1.11$ & 0.006 & 31 \\
\hline & Molecule of $\mathrm{GnRH}$ & Buserelin & Referent & & & & \\
\hline & & Gonadorelin & $-0.02(0.04)$ & 0.98 & $0.90-1.05$ & 0.47 & \\
\hline \multirow[t]{4}{*}{8} & Intercept & & $0.14(0.04)$ & 1.15 & $1.05-1.25$ & 0.002 & 46 \\
\hline & Dose of $\mathrm{hCG}$ & $>2,500 \mathrm{IU}$ & Referent & & & & \\
\hline & & $\leq 1,500 \mathrm{IU}$ & $-0.06(0.07)$ & 0.94 & $0.98-1.07$ & 0.36 & \\
\hline & & $>1,500$ and $\leq 2,500 \mathrm{IU}$ & $-0.16(0.06)$ & 0.85 & $0.74-0.97$ & 0.01 & \\
\hline \multirow[t]{3}{*}{9} & Intercept & & $0.09(0.05)$ & 1.09 & $0.99-1.20$ & 0.06 & 53 \\
\hline & Day of hCG & $\leq 5 \mathrm{~d}$ & Referent & & & & \\
\hline & & $>5 \mathrm{~d}$ & $-0.02(0.06)$ & 1.00 & $0.86-1.10$ & 0.70 & \\
\hline \multirow[t]{4}{*}{10} & Intercept & & $0.14(0.05)$ & 1.15 & $1.03-1.28$ & 0.01 & 39 \\
\hline & Synchronization & $\mathrm{PGF}_{2 \alpha}$ & Referent & & & & \\
\hline & & $\mathrm{GnRH} / \mathrm{PGF}_{2 \alpha}$ & $-0.08(0.06)$ & 0.92 & $0.81-1.03$ & 0.18 & \\
\hline & & Progesterone & $-0.14(0.07)$ & 0.86 & $0.74-1.00$ & 0.06 & \\
\hline
\end{tabular}

${ }^{1} \mathrm{hCG}=$ human chorionic gonadotropin.

(https://doi.org/10.3168/jds.2019-16439). The estimated pooled effect size obtained with the random-effects model 1 (Table 2 ) with no moderator $(\mathrm{RR}=1.07, P=$ 0.0002 ) showed that the treatment was associated with $7 \%$ higher chances of $\mathrm{P} / \mathrm{AI}$ compared with no treatment. The heterogeneity of the data set was moderate $\left(I^{2}=45 \%\right.$; Q statistics: $\chi^{2}=192.42, \mathrm{df}=106, P<$ 0.0001). Including the type of treatment $(\mathrm{GnRH}$ or hCG) in model 2 did not decrease the heterogeneity, and no significant difference between $\mathrm{GnRH}$ and $\mathrm{hCG}$ treatment $(P=0.85)$ was observed.

Inclusion of the fertility status of cows in the metaregression allowed a $6 \%$ reduction in heterogeneity. Treatment with GnRH and hCG resulted in $17 \%$ higher chances of $\mathrm{P} / \mathrm{AI}$ compared with no treatment for cows with very poor, poor, or good fertility $(P>$ 0.05 ) for poor and good groups compared with very poor (model 3, Table 2, Supplemental Figure S1, https: //doi.org/10.3168/jds.2019-16439). Treated cows with very good fertility had $22 \%$ lower chances of $\mathrm{P} / \mathrm{AI}$

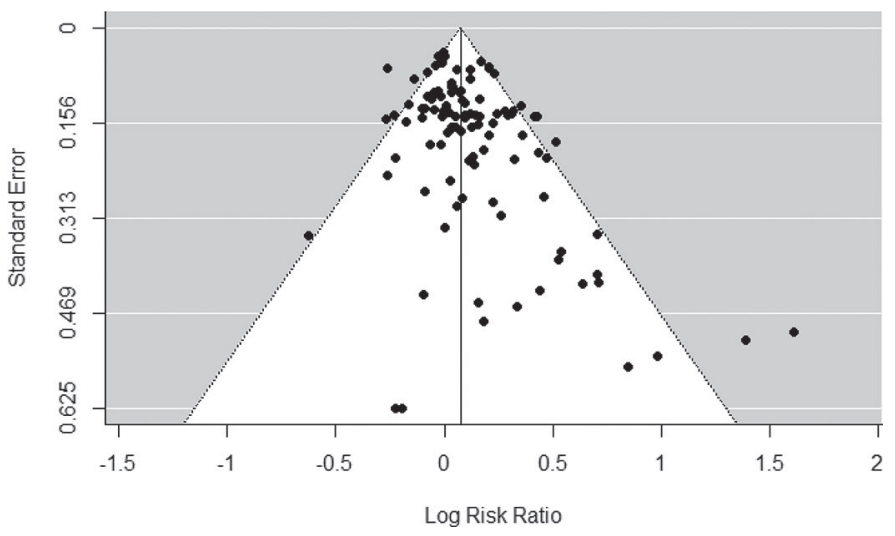

Figure 2. Funnel plots for the meta-regression of model 1. Funnel plots of the effective size of the pregnancy per AI (P/AI; displayed on the horizontal axis) for cows treated with $\mathrm{GnRH}$ and human chorionic gonadotropin (hCG) after AI. 
compared with treated cows with very poor fertility. Moreover, treatment with $\mathrm{GnRH}$ and hCG resulted in 5\% (17-22) lower chances of P/AI compared with no treatment for cows with very good fertility. The related submodel showed that the treatment given to cows with very good fertility was not significantly associated with $\mathrm{P} / \mathrm{AI}(\mathrm{RR}=0.98, P=0.15$, Supplemental Table S2, https://doi.org/10.3168/jds.2019-16439).

Inclusion of the parity of cows in the meta-regression allowed a $3 \%$ reduction in heterogeneity. Treatment with GnRH and hCG resulted in 13\% higher chances of $\mathrm{P} / \mathrm{AI}$ compared with no treatment in primiparous cows (used as the reference class in model 4, Table 2; Supplemental Figure S2, https://doi.org/10.3168/jds .2019-16439). Treated primiparous cows tended to have better treatment efficacy $(P=0.09)$ compared with treated multiparous cows.

Inclusion of the $\mathrm{GnRH}$ dose allowed a $4 \%$ reduction in heterogeneity of the data set (model 5 , Table 2). The moderate dose $(10-10.5 \mu \mathrm{g})$ of $\mathrm{GnRH}$ was associated with $8 \%$ higher chances of $\mathrm{P} / \mathrm{AI}$ for treated cows compared with nontreated cows. No difference between the average and higher doses was observed. Lower chances of $\mathrm{P} / \mathrm{AI}$ were also observed for cows treated with a lower dose compared with cows treated with the moderate dose. This result shows a better $\mathrm{P} / \mathrm{AI}$ for doses $>10 \mu \mathrm{g}$, despite only 4 publications reporting low doses $(<10$ $\mu \mathrm{g})$. The moderator day of $\mathrm{GnRH}$ treatment allowed heterogeneity to be reduced by $10 \%$ (model 6 , Table 2; Supplemental Figure S3, https://doi.org/10.3168/jds .2019-16439). For treated cows, the GnRH treatment administered more than $10 \mathrm{~d}$ after AI was associated with $9 \%$ higher chances of $\mathrm{P} / \mathrm{AI}$ compared with cows treated earlier $(\mathrm{RR}=1.09, P<0.001$; Supplemental Table S2, https://doi.org/10.3168/jds.2019-16439). Including the GnRH molecule in the model reduced heterogeneity but failed to produce a significant difference between the 2 classes (Supplemental Figure S4, https://doi.org/10.3168/jds.2019-16439).

Inclusion of the hCG dose also failed to reduce the heterogeneity of the data set. The higher dose of hCG was associated with $15 \%$ higher chances of $\mathrm{P} / \mathrm{AI}$ for treated cows compared with nontreated cows; moreover, $15 \%$ lower chances of $\mathrm{P} / \mathrm{AI}$ were observed for cows given a moderate dose compared with cows treated with the highest dose $(\mathrm{RR}=0.85, P=0.01)$. The moderator day of hCG was not significantly associated with the chances of $\mathrm{P} / \mathrm{AI}$, and its inclusion in the model did not allow a reduction in heterogeneity (model 9, Table 2).

Inclusion of synchronization protocol type allowed a $6 \%$ reduction in heterogeneity of the data set (model 10, Table 2). Cows treated with $\mathrm{PGF}_{2 \alpha}$ had $15 \%$ higher chances of $\mathrm{P} / \mathrm{AI}$ compared with nontreated cows. A trend toward lower P/AI was observed for other synchronization protocols.

The other moderators listed in Table 1 did not reduce the residual heterogeneity of the models and were not associated with statistically significant explanatory variables.

Table 3 reports the final bivariate meta-regressions. Adding the moderators fertility and parity (model 2.1), fertility and GnRH molecule (model 2.2), and dose and day of GnRH treatment (model 2.3) allowed for decreases in heterogeneity of 6,25 , and $13 \%$, respectively, compared with the model with the moderator fertility (model 3). For nulliparous or primiparous cows with very poor fertility, $44 \%$ higher chances of $\mathrm{P} / \mathrm{AI}$ were observed in cases of treatment compared with no treatment (model 2.1, Figure 3). The treatment was a less effective for primiparous cows with poor fertility, with $25 \%$ (44-19) higher chances of $\mathrm{P} / \mathrm{AI}$ were observed in cases of treatment compared with no treatment. For multiparous cows with poor fertility, $16 \%$ (37-21) higher chances of $\mathrm{P} / \mathrm{AI}$ were observed in cases of treatment compared with no treatment. For cows with very poor, poor, and even good fertility and treated with buserelin, $17 \%$ higher chances of $\mathrm{P} / \mathrm{AI}$ in cases of treatment compared with no treatment were observed (model 2.2, Figure 4). Cows treated with moderate and high doses of buserelin more than $10 \mathrm{~d}$ after AI had $11 \%$ higher chances of $\mathrm{P} / \mathrm{AI}$ in cases of treatment compared with no treatment (model 2.3 Figure 5).

The models including parity and synchronization protocols did not allow a reduction in heterogeneity. Collinearity between the moderators synchronization and fertility was observed, with less fertile cows being more likely to be synchronized. No other bivariable models were statistically significant, and no interaction was observed for either of the models.

The sensitivity analysis indicated 2,3 , and 1 outliers for the final models $2.1,2.2$, and 2.3 , respectively (Supplemental Figure S5, https://doi.org/10.3168/jds .2019-16439), but exclusion did not change the significant associations or the coefficient that was observed in the final meta-regressions, which have been retained as final meta-regression models.

\section{DISCUSSION}

The present meta-analysis focuses on the association between hCG or GnRH treatment and P/AI in cows. Two types of coefficients were provided, and 3 kinds of models were constructed. The first type of coefficient is that of the intercept (effect size), which represents the $\mathrm{RR}$ for $\mathrm{P} / \mathrm{AI}$ in the case of treatment compared with no treatment. When the regression was performed on the 
whole data set without a moderator, the mean effect size $(\mathrm{RR}=1.07$ Table 2 , kind 1$)$ represents the mean efficacy of the treatment. When the regression was performed to a subset of data without a moderator, the effect size represents the mean efficacy of the treatment for the subpopulation selected (Supplemental Table S2, kind 2, https://doi.org/10.3168/jds.2019-16439). When the regression includes a moderator(s), the effect size represents the mean efficacy of the treatment for the subpopulation(s) sectioned as reference(s) (Tables 2 and 3, kind 3). The second type of coefficients are those that were obtained for the moderators and associated risk; they represent the $\mathrm{RR}$ for $\mathrm{P} / \mathrm{AI}$ for the selected class compared with the reference class. The coefficient (or RR) then compares 2 types of treatment or 2 conditions of treatment used, with the reference being the reference class of the moderator.

The meta-analysis was conducted according to standard recommendations (Viechtbauer, 2010; Schwarzer et al., 2015). The final choices for the models were selected on the basis of decreased heterogeneity. More than one model was reported for the same outcome because the authors judged all of these models to have biological significance and to be of interest to the scientific community. The bivariate models provided in Table 3 show close coefficients compared with the univariate models that are provided in Table 2, and the addition of a new moderator allows reduced heterogeneity. This observation suggests a low collinearity between the moderators that are included in the univariate models, in accordance with the collinearity tests that were performed at the start of the study (data not shown) for the moderators of interest. In the present data set, synchronization with $\mathrm{PGF}_{2 \alpha}$ or the combination of $\mathrm{GnRH} / \mathrm{PGF}_{2 \alpha}$ (Ovsynch or Presynch) was more frequently used in cows with low fertility, suggesting that readers should focus on model 10 (Table 2).

Previous studies showed that administration of GnRH, a GnRH agonist, or hCG after AI is coincident with the presence of the dominant follicle in the first and second follicular waves, which may stimulate CL function, induce accessory CL formation, increase P4 concentration, and reduce estrogen production with a consequent positive effect on embryonic survival (Stevenson et al., 2007). In addition to inducing an accessory CL and increasing progesterone after AI, ovulation of a first-wave follicle can change follicular dynamics at the time of luteolysis, thereby extending the time of luteolysis and allowing more time for an embryo to elongate (Araujo et al., 2009). The present study provides an update on the association between GnRH or hCG treatments administered between 4 and $15 \mathrm{~d}$ after $\mathrm{AI}$ and P/AI.

The results show that treatments with GnRH and hCG improve P/AI in cows with low fertility (very poor $<30 \%$ and poor 30.1 to $45 \%$ ), whereas treatment of cows with very good fertility $(>60.1 \%)$ did not result in any benefit. The low fertility (poor and very poor) may result from poor ovulation, inappropriately timed estrus or simply insufficient endogenous circulating P4 to support the survival of the early embryo. A lower P4 concentration has been measured in low-fertility cows after estrus (Shelton et al., 1990). Cows with good fertility do not need treatment to improve luteal func-

Table 3. Results of the bivariate meta-regressions

\begin{tabular}{|c|c|c|c|c|c|c|c|}
\hline $\begin{array}{l}\text { Model } \\
\text { no. }\end{array}$ & Moderator & Class & Estimate (SE) & Risk ratio & $95 \%$ CI & $P$-value & $I^{2} \%$ \\
\hline \multirow[t]{5}{*}{2.1} & Intercept & & $0.37(0.10)$ & 1.44 & $1.18-1.78$ & 0.002 & 37 \\
\hline & \multirow[t]{3}{*}{ Fertility } & Very poor & Referent & & & & \\
\hline & & Good & $-0.37(0.11)$ & 0.69 & $0.54-0.87$ & 0.001 & \\
\hline & & Very good & $-0.24(0.19)$ & 0.78 & $0.54-1.13$ & 0.2 & \\
\hline & Parity & Primiparous & Referent & & & & \\
\hline \multirow[t]{7}{*}{2.2} & Intercept & & $0.16(0.07)$ & 1.17 & $1.02-1.36$ & 0.01 & 0 \\
\hline & \multirow{4}{*}{ Fertility } & Very poor & Referent & & & & \\
\hline & & Poor & $0.01(0.06)$ & 1.01 & $0.91-1.13$ & 0.74 & \\
\hline & & Good & $0.008(0.06)$ & 1.04 & $0.88-1.15$ & 0.90 & \\
\hline & & Very good & $-0.17(0.07)$ & 0.63 & $0.72-0.98$ & 0.01 & \\
\hline & \multirow[t]{2}{*}{ Molecule } & Buserelin & Referent & & & & \\
\hline & & Gonadorelin & $-0.14(0.05)$ & 0.86 & $0.77-0.98$ & 0.01 & \\
\hline 2.3 & (buserelin only) & $\leq 10 \mathrm{~d}$ & $-0.11(0.04)$ & 0.89 & $0.81-0.97$ & 0.004 & \\
\hline
\end{tabular}


tion because they probably already have adequate P4 for embryo development and the subsequent signaling of pregnancy to the cow. In such situations, treatment with GnRH or hCG was not beneficial to P/AI. Supplementation with $\mathrm{P} 4$ has previously been reported to increase $\mathrm{P} / \mathrm{AI}$ in herds with low fertility (Robinson et al., 1989; Van Cleeff et al., 1991; Yan et al., 2016), which is consistent with the present study. Increased embryonic survival was observed at $\mathrm{P} 4$ concentrations above $3 \mathrm{ng} /$ $\mathrm{mL}$ and decreased embryonic survival at $\mathrm{P} 4$ concentrations higher than $9 \mathrm{ng} / \mathrm{mL}$, indicating that low and high $\mathrm{P} 4$ concentrations are both associated with a low embryo survival rate (Starbuck et al., 2001). The upper limit of $\mathrm{P} 4$, whether occurring by $\mathrm{P} 4$ supplementation or spontaneously, was actually detrimental to embryo survival and may have caused embryo loss by excessive growth stimulation, thus leading to asynchrony between the embryo and its environment.

The present work shows that treatment with GnRH and hCG improved P/AI in primiparous cows. Primiparous cows belong, generally, to a category of animals with very poor fertility. Therefore, the P/AI was greatly improved after their treatment. Primiparous cows have many physiological and pathological differences from multiparous cows, including lower milk production, fewer reproductive problems, increased anovulation, fewer disease problems, and reduced body and organ sizes compared with their counterparts (Bamber et al.,

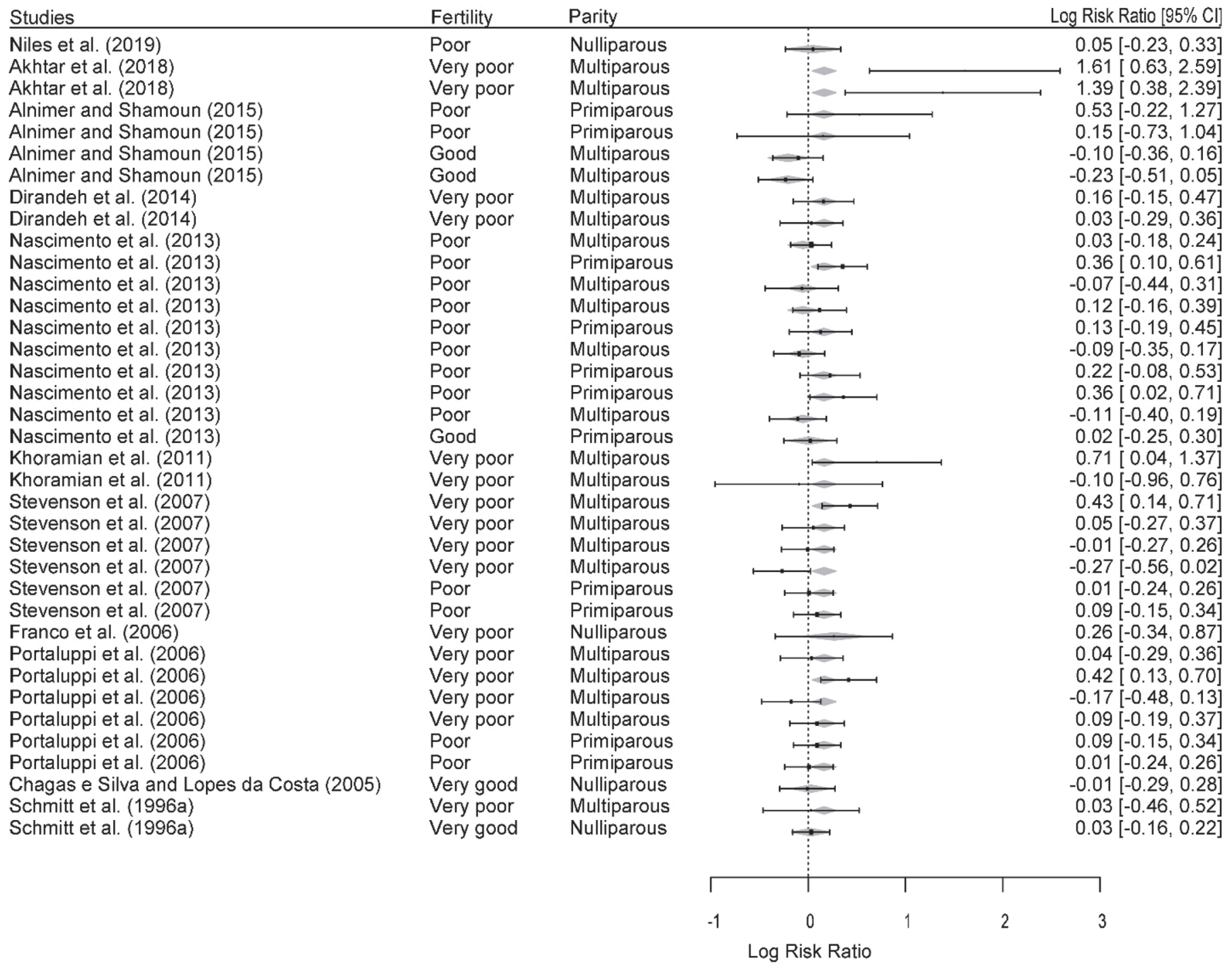

Figure 3. Forest plot for model 2.1. Log risk ratio (RR) and 95\% CI of studies on the effect of fertility and parity on pregnancy per AI (P/ AI). The gray diamonds represent the predicted effect sizes using the meta-regression model. 
Studies Fertility Molecule of GnRH

Log Risk Ratio [95\% Cl]

Kunde et al. (2018)

Mendonça et al. (2017)

Jeong et al. (2016)

Dirandeh et al. (2014)

Dirandeh et al. (2014)

Birhanu et al. (2014)

Jaswal and Singh (2013)

Jaswal and Singh (2013)

Jaswal and Singh (2013)

Jaswal and Singh (2013)

Khoramian et al. (2011)

Vasconcelos et al. (2011)

Ataman et al. (2011)

Ataman et al. (2011)

Velázquez et al. (2009)

Velázquez et al. (2009)

Beltran and Vasconcelos (2008)

Stevenson et al. (2007)

Stevenson et al. (2007)

Stevenson et al. (2007)

Franco et al. (2006)

Franco et al. (2006)

Franco et al. (2006)

Franco et al. (2006)

Franco et al. (2006)

Howard et al. (2006)

Portaluppi et al. (2006)

Portaluppi et al. (2006)

Portaluppi et al. (2006)

Sterry et al. (2006)

Bartolome et al. (2005)

Bartolome et al. (2005)

Willard et al. (2003)

Willard et al. (2003)

Tefera et al. (2001)

Muir et al. (1998)

Taufa et al. (1998)

Drew and Peters (1994)

Ryan et al. (1994)

Drew and Peters (1994)

Drew and Peters (1994)

Stevenson et al. (1993)

Sheldon and Dobson (1993)

Lajili et al. (1991)

Lajili et al. (1991)

Lewis et al. (1990)

Jubb et al. (1990)

Leslie et al. (1986)

Macmillan et al. (1986)

Macmillan et al. (1986)

Macmillan et al. (1986)

Macmillan et al. (1986)

Macmillan et al. (1986)

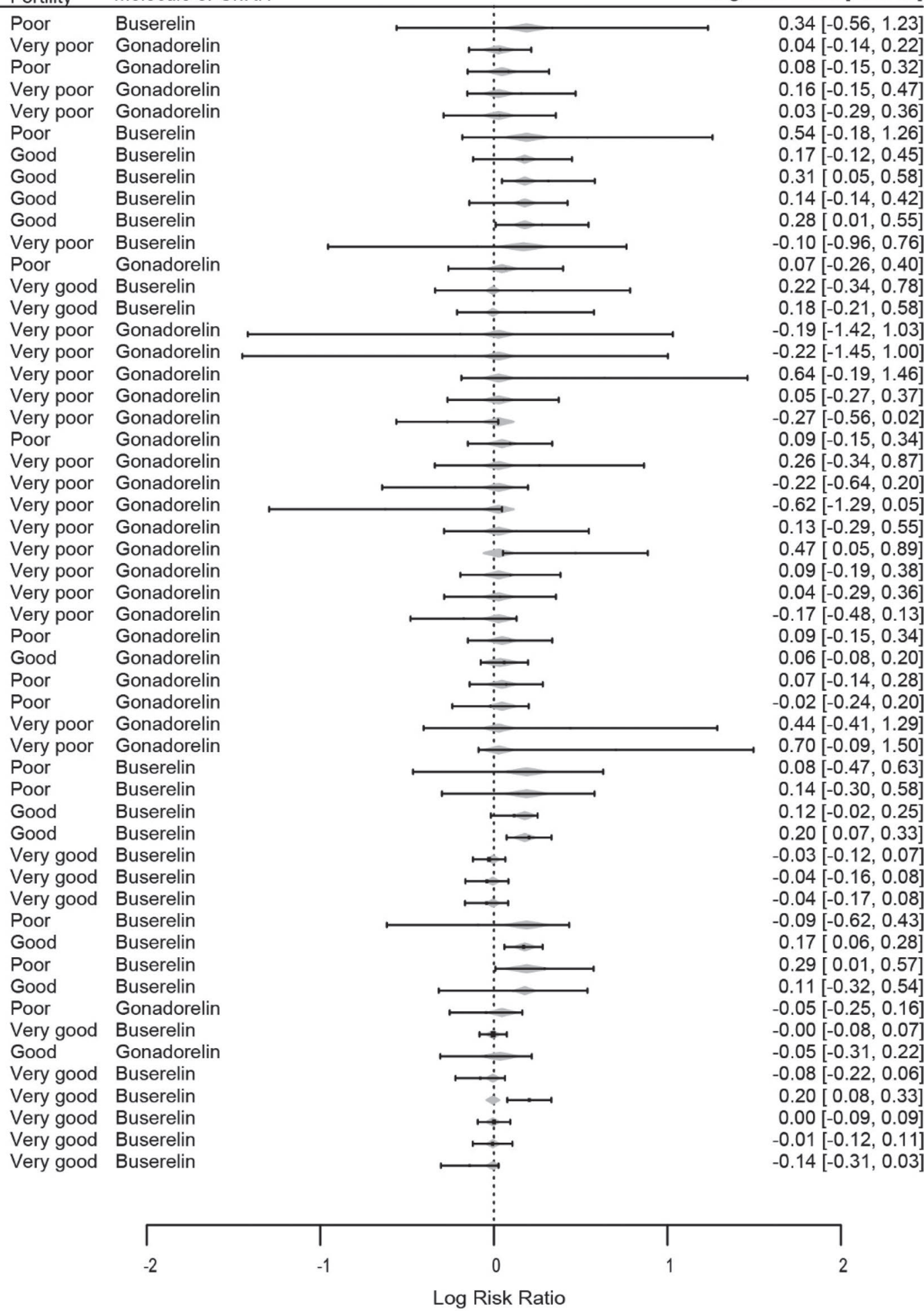

Log Risk Ratio

Figure 4. Forest plot for model 2.2. Log risk ratio (RR) and 95\% CI of studies on the effect of fertility and GnRH molecule used after AI on pregnancy per AI (P/AI). The gray diamonds represent the predicted effect sizes using the meta-regression model. 
2009). Any or all of these issues may underlie the parity differences that were observed between studies.

Treatment with a medium or high dose $(>10 \mu \mathrm{g})$ of buserelin was associated with greater $\mathrm{P} / \mathrm{AI}$ compared with low-dose buserelin treatments. A higher dose of GnRH may have enhanced LH secretion within 2 to $4 \mathrm{~h}$ of administration in peripheral circulation, which in turn increased the ovulation rate (Chenault et al., 1990). In contrast, no effect was observed with low $(<10 \mu \mathrm{g})$ buserelin doses in another study (Nakao et al., 1992). An intramuscular injection of buserelin at a dose of $10 \mu \mathrm{g}$ or higher was reported to be as effective as intramuscular administration of 10,000 IU of hCG for the treatment of ovarian follicular cysts in cows. However, lower results for the treatment of ovarian follicular cysts were observed after treatment with a very small dose of buserelin $(6 \mu \mathrm{g})$.

Treatment with buserelin was associated with higher $\mathrm{P} / \mathrm{AI}$ compared with treatment with gonadorelin in the final model 2.2. The characteristics of the GnRHinduced LH surge profile due to the estrous cycle phase or season were independent of the type of $\mathrm{GnRH}$ (gonadorelin vs. buserelin) that was used in a study (Armengol-Gelonch et al., 2017). Moreover, the 3 GnRH analogs (gonadorelin, lecirelin, and buserelin), at the doses indicated for induction of ovulation, are almost equally effective for inducing the disappearance of the dominant follicle at $\mathrm{d} 6$ to 7 of the estrous cycle (Picard-Hagen et al., 2015).

In the present work, GnRH treatment after d 10 post-AI was associated with higher $\mathrm{P} / \mathrm{AI}$ compared with GnRH treatment before d 10 post-AI. This finding is not in accordance with previous results showing that the ovulatory response to GnRH is not very good after d 10 of the cycle due to the lack of a dominant follicle, particularly from d 10 to 14 in 2 -wave cows, and the inhibitory effect of high progesterone on the induction of an LH surge (Giordano et al., 2012). The results observed in the present study are in accordance with the fact that the administration of $\mathrm{GnRH}$ after $10 \mathrm{~d}$ coincides with the critical period of maternal recognition of pregnancy and before the initiation of the luteolytic

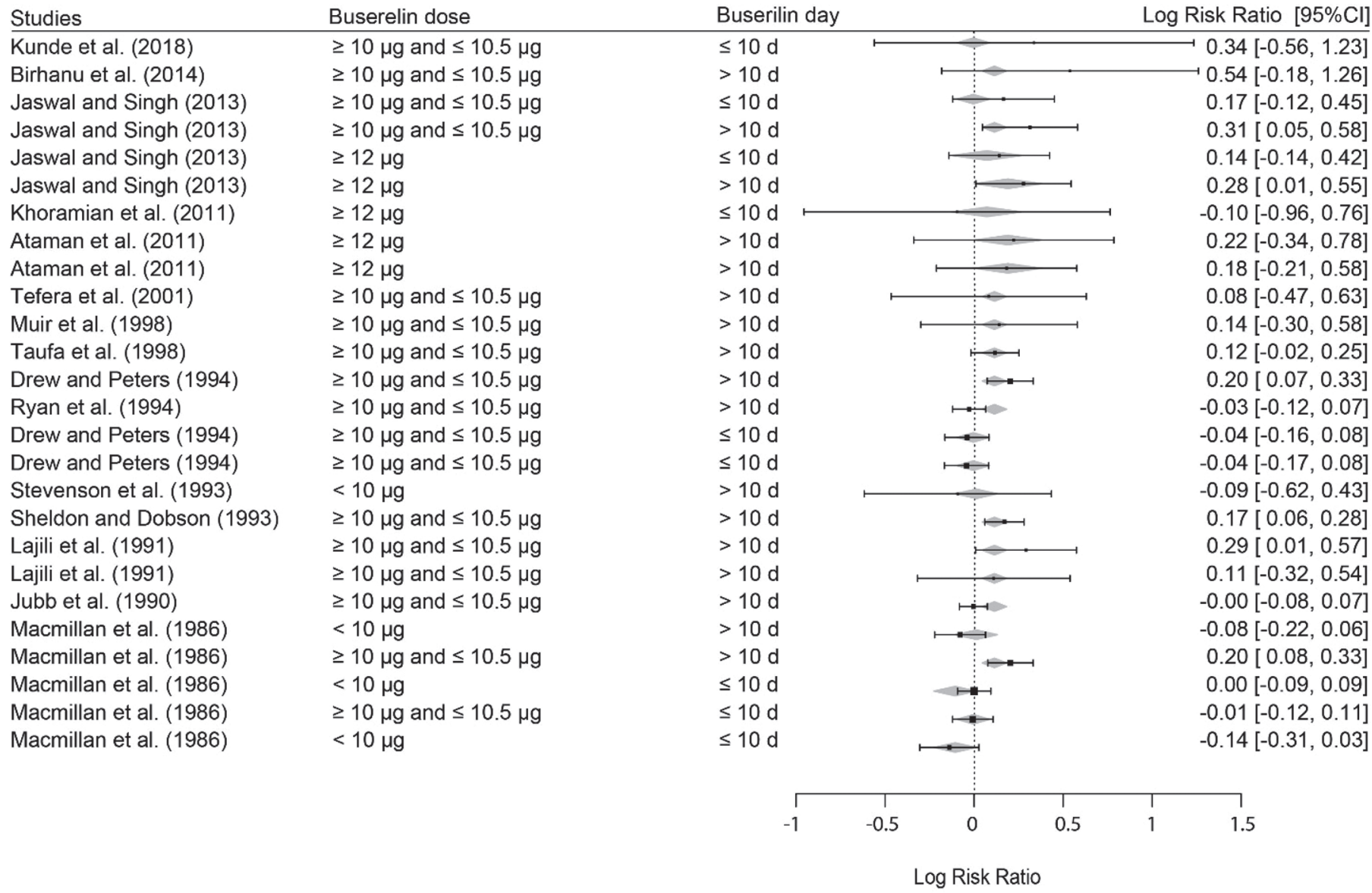

Figure 5. Forest plot for model 2.3. Log risk ratio (RR) and 95\% CI of studies on the effective dose and day of treatment with buserelin on pregnancy per AI (P/AI). The gray diamonds represent the predicted effect sizes using the meta-regression model. 
mechanism characterized by the embryonic secretion of antiluteolytic factors (Mann and Lamming, 2001). Treatment with GnRH induces ovulation or luteinization of the dominant follicle and the formation of accessory CL. Consequently, GnRH treatment increases P4 and decreases the estradiol concentration. A lower serum concentration of estradiol during d 14 to 17 after AI has been associated with higher $\mathrm{P} / \mathrm{AI}$ in lactating beef cows (Pritchard et al., 1994).

A high hCG dose $(>2,500 \mathrm{IU})$ was associated with increased $\mathrm{P} / \mathrm{AI}$ in the present work. A review of $\mathrm{hCG}$ treatment after AI (De Rensis et al., 2010) indicated that an hCG dose ranging from 1,000 to $10,000 \mathrm{IU}$ did not seem to affect the ovarian response.

No difference in the nature of the treatment (hCG or $\mathrm{GnRH}$ ) was observed. The GnRH and hCG treatments have similar effects on the ovary (Fricke et al., 1993), induction of ovulation (Burns et al., 2008), and formation of accessory CL (Schmitt et al., 1996b).

\section{CONCLUSIONS}

The present meta-analysis quantifies the change in $\mathrm{P} / \mathrm{AI}$ in cases of treatment with $\mathrm{GnRH}$ and $\mathrm{hCG}$ compared with no treatment. The meta-analysis suggests that in certain circumstances $\mathrm{GnRH}$ and hCG may produce significant benefits. It did not show any difference between GnRH and hCG. Treatment with GnRH and hCG improved P/AI in primiparous cows with low fertility, whereas treatment of cows with good fertility did not gain any benefit. A buserelin treatment above $10 \mu \mathrm{g}$, with an hCG dose above 2,500 IU and a $\mathrm{GnRH}$ treatment after d 10 post-AI, were associated with higher $\mathrm{P} / \mathrm{AI}$ compared with lower doses and earlier treatment.

\section{REFERENCES}

Akhtar, M. S., M. Saleem, E. Ahmad, T. Ahmad, M. H. Lashari, M. M. Ayaz, L. A. Lodhi, I. Ahmad, I. Hussain, and M. Akhtar. 2018. Effect of lecirelin acetate, hCG or progesterone administration on day 7 post-insemination on conception rate and progesterone concentration in cross-bred cattle. Iraqi J. Vet. Sci. 32:149-152.

Alnimer, M. A., and A. I. Shamoun. 2015. Treatment with hCG 4 or 6 days after TAI to improve pregnancy outcomes in repeat-breeding dairy cows. Anim. Reprod. Sci. 157:63-70. https://doi.org/10 .1016/j.anireprosci.2015.03.016.

Araujo, R. R., O. J. Ginther, J. C. Ferreira, M. M. Palha, M. A. Beg, and M. C. Wiltbank. 2009. Role of follicular estradiol-17beta in timing of luteolysis in heifers. Biol. Reprod. 81:426-437. https:// doi.org/10.1095/biolreprod.108.073825.

Armengol-Gelonch, R., J. M. Mallo, D. Ponté, A. Jimenez, A. Valenza, and A. H. Souza. 2017. Impact of phase of the estrous cycle and season on LH surge profile and fertility in dairy cows treated with different $\mathrm{GnRH}$ analogs (gonadorelin vs. buserelin). Theriogenology 91:121-126. https://doi.org/10.1016/j.theriogenology.2017.01 .001 .
Ataman, M. B., H. Erdem, B. Bülbül, S. Ümütlü, and M. Çolak. 2011. The effect of buserelin injection 12 days after insemination on selected reproductive characteristics in cows. Acta Vet. Brno 80:171-177. https://doi.org/10.2754/avb201180020171.

Bamber, R. L., G. E. Shook, M. C. Wiltbank, J. E. P. Santos, and P. M. Fricke. 2009. Genetic parameters for anovulation and pregnancy loss in dairy cattle. J. Dairy Sci. 92:5739-5753. https://doi .org/10.3168/jds.2009-2226.

Bartolome, J. A., P. Melendez, D. Kelbert, K. Swift, J. McHale, J. Hernandez, F. Silvestre, C. A. Risco, A. C. M. Arteche, W. W. Thatcher, and L. F. Archbald. 2005. Strategic use of gonadotrophin-releasing hormone $(\mathrm{GnRH})$ to increase pregnancy rate and reduce pregnancy loss in lactating dairy cows subjected to synchronization of ovulation and timed insemination. Theriogenology 63:1026-1037. https://doi.org/10.1016/j.theriogenology.2004 .05 .020 .

Bello, N. M., J. S. Stevenson, and R. J. Tempelman. 2012. Invited review: Milk production and reproductive performance: Modern interdisciplinary insights into an enduring axiom. J. Dairy Sci. 95:5461-5475. https://doi.org/10.3168/jds.2012-5564.

Beltran, M. P., and J. L. M. Vasconcelos. 2008. Conception rate in Holstein cows treated with GnRH or hCG on the fifth day post artificial insemination during summer. Arq. Bras. Med. Vet. Zootec. 60:580-586. https://doi.org/10.1590/S0102-09352008000300009.

Birhanu, H., G. Berihu, A. Gezahign, and T. Teshale. 2014. Effects of buserelin acetate on conception rate in repeat breeding dairy cattle. Indian J. Anim. Reprod. 35:47-49.

Burns, M. G., B. S. Buttrey, C. A. Dobbins, C. A. Martel, K. C. Olson, G. C. Lamb, and J. S. Stevenson. 2008. Evaluation of human chorionic gonadotropin as a replacement for gonadotropin-releasing hormone in ovulation-synchronization protocols before fixed timed artificial insemination in beef cattle. J. Anim. Sci. 86:2539-2548. https://doi.org/10.2527/jas.2008-1122.

Carvalho, P. D., V. G. Santos, J. O. Giordano, M. C. Wiltbank, and P. M. Fricke. 2018. Development of fertility programs to achieve high 21-day pregnancy rates in high-producing dairy cows. Theriogenology 114:165-172. https://doi.org/10.1016/j.theriogenology .2018.03.037.

Chagas e Silva, J., and L. Lopes da Costa. 2005. Luteotrophic influence of early bovine embryos and the relationship between plasma progesterone concentrations and embryo survival. Theriogenology 64:49-60. https://doi.org/10.1016/j.theriogenology.2004.10.019.

Chenault, J. R., D. D. Kratzer, R. A. Rzepkowski, and M. C. Goodwin. 1990. LH and FSH response of Holstein heifers to fertirelin acetate, gonadorelin and buserelin. Theriogenology 34:81-98. https:/ /doi.org/10.1016/0093-691x(90)90579-i.

De Rensis, F., F. López-Gatius, I. García-Ispierto, and M. Techakumpu. 2010. Clinical use of human chorionic gonadotropin in dairy cows: An update. Theriogenology 73:1001-1008. https://doi.org/ 10.1016/j.theriogenology.2009.11.027.

Dirandeh, E., A. R. Roodbari, and B. Shohreh. 2014. Effect of GnRH injection at day 6 and 12 after insemination on fertility of Holstein. Int. J. Adv. Biol. Biomed. Res. 2:125-131.

Drew, S. B., and A. Peters. 1994. Effect of buserelin on pregnancy rates in dairy cows. Vet. Rec. 134:267-269. https://doi.org/10 $.1136 / v r .134 .11 .267$.

Egger, M., G. D. Smith, and A. N. Phillips. 1997. Meta-analysis: Principles and procedures. BMJ 315:1533-1537. https://doi.org/10 $.1136 /$ bmj.315.7121.1533.

Franco, M., P. M. Thompson, A. M. Brad, and P. J. Hansen. 2006. Effectiveness of administration of gonadotropin-releasing hormone at Days 11, 14 or 15 after anticipated ovulation for increasing fertility of lactating dairy cows and non-lactating heifers. Theriogenology 66:945-954. https://doi.org/10.1016/j.theriogenology.2005.12.014.

Fricke, P. M., L. P. Reynolds, and D. A. Redmer. 1993. Effect of human chorionic gonadotropin administered early in the estrous cycle on ovulation and subsequent luteal function in cows. J. Anim. Sci. 71:1242-1246. https://doi.org/10.2527/1993.7151242x.

Giordano, J. O., P. M. Fricke, J. N. Guenther, G. L. Jr, M. M. Herlihy, A. B. Nascimento, and M. C. Wiltbank. 2012. Effect of proges- 
terone on magnitude of the luteinizing hormone surge induced by two different doses of gonadotropin-releasing hormone in lactating dairy cows. J. Dairy Sci. 95:3781-3793. https://doi.org/10.3168/ jds.2011-5155.

Higgins, J. P. T., and S. G. Thompson. 2002. Quantifying heterogeneity in a meta-analysis. Stat. Med. 21:1539-1558. https://doi.org/ $10.1002 / \operatorname{sim} .1186$

Howard, J. M., R. Manzo, J. C. Dalton, F. Frago, and A. Ahmadzadeh. 2006. Conception rates and serum progesterone concentration in dairy cattle administered gonadotropin releasing hormone 5 days after artificial insemination. Anim. Reprod. Sci. 95:224-233. https://doi.org/10.1016/j.anireprosci.2005.10.010.

Jaswal, R. S., and M. Singh. 2013. The effect of administration of gonadotropin releasing hormone analogue at estrus or during luteal phase on reproductive performance of dairy cows maintained under sub-temperate climate. Majallah-i Tahqiqat-i Dampizishki-i Iran 14:57-60.

Jeong, J. K., I. S. Choi, H. G. Kang, T. Y. Hur, and I. H. Kim. 2016. Effects of gonadotropin-releasing hormone administration or a controlled internal drug-releasing insert after timed artificial insemination on pregnancy rates of dairy cows. J. Vet. Sci. 17:577-582. https://doi.org/10.4142/jvs.2016.17.4.577.

Jubb, T. F., D. Abhayaratnet, J. Malmos, and G. A. Anderson. 1990. Failure of an intramuscular injection of an analogue of gonadotrophin-releasing hormone 11 to 13 days after insemination to increase pregnancy rates in dairy cattle. Aust. Vet. J. 67:359-361. https://doi.org/10.1111/j.1751-0813.1990.tb07402.x.

Khoramian, B., N. Farzaneh, M. T. Garoussi, and M. Mohri. 2011. Comparison of the effects of gonadotropin-releasing hormone, human chorionic gonadotropin or progesterone on pregnancy per artificial insemination in repeat-breeder dairy cows. Res. Vet. Sci. 90:312-315. https://doi.org/10.1016/j.rvsc.2010.05.025.

Kunde, A., M. Raju, and K. Murugavel. 2018. Use of progesteronebased FTAI protocol followed by GnRH or hCG treatment on day 6 post-AI in repeat breeder cattle. Indian J. Anim. Reprod. 39:1.

Lajili, H., P. Humblot, and M. Thibier. 1991. Effect of PG F2 alpha treatment on conception rates of dairy cows treated with a $\mathrm{GnRH}$ agonist 12 to 14 days after artificial insemination. Theriogenology 36:335-347. https://doi.org/10.1016/0093-691x(91)90391-p.

Leslie, K. E., W. T. K. Bosu, K. Lissemore, and D. Kelton. 1986. The effects of gonadotrophin releasing hormone administration four days after insemination on first-service conception rates and corpus luteum function in dairy cows. Can. J. Vet. Res. 50:184-187.

Lewis, G. S., D. W. Caldwell, C. E. R. Jr, H. H. Dowlen, and J. R. Owen. 1990. Effects of gonadotropin-releasing hormone and human chorionic gonadotropin on pregnancy rate in dairy cattle. J. Dairy Sci. 73:66-72. https://doi.org/10.3168/jds.S0022-0302(90)78647 $-\mathrm{X}$.

Lonergan, P. 2011. Influence of progesterone on oocyte quality and embryo development in cows. Theriogenology 76:1594-1601. https: //doi.org/10.1016/j.theriogenology.2011.06.012.

Lucy, M. C. 2001. Reproductive loss in high-producing dairy cattle: Where will it end? J. Dairy Sci. 84:1277-1293. https://doi.org/10 .3168/jds.S0022-0302(01)70158-0.

Macmillan, K. L., V. K. Taufa, and A. M. Day. 1986. Effects of an agonist of gonadotrophin releasing hormone (Buserelin) in cattle. III. Pregnancy rates after a post-insemination injection during metoestrus or dioestrus. Anim. Reprod. Sci. 11:1-10. https://doi .org/10.1016/0378-4320(86)90096-5.

Mann, G. E., and G. E. Lamming. 2001. Relationship between maternal endocrine environment, early embryo development and inhibition of the luteolytic mechanism in cows. Reproduction 121:175180. https://doi.org/10.1530/rep.0.1210175.

Mendonça, L. G. D., F. M. Mantelo, and J. S. Stevenson. 2017. Fertility of lactating dairy cows treated with gonadotropin-releasing hormone at AI, 5 days after AI, or both, during summer heat stress. Theriogenology 91:9-16. https://doi.org/10.1016/j.theriogenology .2016.11.032.

Muir, M. R., A. Stannett, J. E. Offer, P. J. H. Ball, C. Taylor, and D. N. Logue. 1998. Oestrus synchronisation combined with buserelin administration in beef cattle. Vet. Rec. 143:143-144. https://doi .org/10.1136/vr.143.5.143.

Nakao, T., M. Tomita, H. Kanbayashi, H. Takagi, T. Abe, Y. Takeuchi, H. Ochiai, M. Moriyoshi, and K. Kawata. 1992. Comparisons of several dosages of a $\mathrm{GnRH}$ analog with the standard dose of $\mathrm{hCG}$ in the treatment of follicular cysts in dairy cows. Theriogenology 38:137-145. https://doi.org/10.1016/0093-691x(92)90225-g.

Nascimento, A. B., R. W. Bender, A. H. Souza, H. Ayres, R. R. Araujo, J. N. Guenther, R. Sartori, and M. C. Wiltbank. 2013. Effect of treatment with human chorionic gonadotropin on day 5 after timed artificial insemination on fertility of lactating dairy cows. J. Dairy Sci. 96:2873-2882. https://doi.org/10.3168/jds.2012-5895.

Niles, A. M., H. P. Fricke, P. D. Carvalho, M. C. Wiltbank, L. L. Hernandez, and P. M. Fricke. 2019. Effect of treatment with human chorionic gonadotropin 7 days after artificial insemination or at the time of embryo transfer on reproductive outcomes in nulliparous Holstein heifers. J. Dairy Sci. 102:2593-2606. https://doi.org/ $10.3168 /$ jds.2018-15588.

Peters, A. R., T. A. Martinez, and A. J. C. Cook. 2000. A meta-analysis of studies of the effect of GnRH 11-14 days after insemination on pregnancy rates in cattle. Theriogenology 54:1317-1326. https: //doi.org/10.1016/s0093-691x(00)00438-6.

Picard-Hagen, N., G. Lhermie, S. Florentin, D. Merle, P. Frein, and V. Gayrard. 2015. Effect of gonadorelin, lecirelin, and buserelin on LH surge, ovulation, and progesterone in cattle. Theriogenology 84:177-183. https://doi.org/10.1016/j.theriogenology.2015.03.004.

Portaluppi, M. A., D. E. Tenhouse, A. Lloyd, and D. R. Eborn. 2006 Ovarian responses and conception rates in response to $\mathrm{GnRH}$ hCG, and progesterone. Kansas Agric. Exp. Stn. Res. Reports 2:26-31. https://doi.org/10.4148/2378-5977.3155.

Pritchard, J. Y., F. N. Schrick, and E. K. Inskeep. 1994. Relationship of pregnancy rate to peripheral concentrations of progesterone and estradiol in beef cows. Theriogenology 42:247-259. https://doi .org/10.1016/0093-691x(94)90269-0.

Robinson, N. A., K. E. Leslie, and J. S. Walton. 1989. Effect of treatment with progesterone on pregnancy rate and plasma concentrations of progesterone in Holstein cows. J. Dairy Sci. 72:202-207. https://doi.org/10.3168/jds.S0022-0302(89)79098-6.

Ryan, D. P., S. Snijders, T. Condon, M. Grealy, J. Sreenan, and K. J. O'Farrell. 1994. Endocrine and ovarian responses and pregnancy rates in dairy cows following the administration of a gonadotrophin releasing hormone analog at the time of artificial insemination or at mid-cycle post insemination. 34:179-191. Anim. Reprod. Sci. https://doi.org/10.1016/0378-4320(94)90015-9.

Schmitt, É. J. P., T. Diaz, C. M. Barros, R. L. De La Sota, M. Drost, E. W. Fredriksson, C. R. Staples, R. Thorner, and W. W. Thatcher. 1996a. Differential response of the luteal phase and fertility in cattle following ovulation of the first-wave follicle with human chorionic gonadotropin or an agonist of gonadotropin-releasing hormone. J. Anim. Sci. 74:1074-1083. https://doi.org/10.2527/ 1996.7451074x.

Schmitt, É. J. P., T. Diaz, M. Drost, and W. W. Thatcher. 1996b. Use of a gonadotropin-releasing hormone agonist or human chorionic gonadotropin for timed insemination in cattle. J. Anim. Sci. 74:1084-1091. https://doi.org/10.2527/1996.7451084x.

Schwarzer, G., J. R. Carpenter, and G. Rücker. 2015. Meta-Analysis with R. (Use R!). Springer International Publishing, Basel, Switzerland.

Sheldon, I. M., and H. Dobson. 1993. Effects of gonadotrophin releasing hormone administered 11 days after insemination on the pregnancy rates of cattle to the first and later services. Vet. Rec. 133:160-163. https://doi.org/10.1136/vr.133.7.160.

Shelton, K., M. F. Gayerie De Abreu, M. G. Hunter, T. J. Parkinson, and G. E. Lamming. 1990. Luteal inadequacy during the early luteal phase of subfertile cows. J. Reprod. Fertil. 90:1-10. https:// doi.org/10.1530/jrf.0.0900001.

Spencer, T. E., and T. R. Hansen. 2015. Implantation and establishment of pregnancy in ruminants. Springer. Pages 105-135 in Regulation of Implantation and Establishment of Pregnancy in Mammals. Springer, Cham, Switzerland. 
Starbuck, G. R., A. O. Darwash, G. E. Mann, and G. E. Lamming. 2001. The detection and treatment of post insemination progesterone insufficiency in dairy cows. BSAP Occas. Publ. 26:447-450. https://doi.org/10.1017/S0263967X00034091.

Sterry, R. A., M. L. Welle, and P. M. Fricke. 2006. Treatment with gonadotropin-releasing hormone after first timed artificial insemination improves fertility in noncycling lactating dairy cows. J. Dairy Sci. 89:4237-4245. https://doi.org/10.3168/jds.S0022 -0302(06)72469-9.

Stevenson, J. S., A. P. Phatak, I. Rettmer, and R. E. Stewart. 1993. Postinsemination administration of Receptal: Follicular dynamics, duration of cycle, hormonal responses, and pregnancy rates. J. Dairy Sci. 76:2536-2547. https://doi.org/10.3168/jds.S0022 -0302(93) 77589-X.

Stevenson, J. S., M. A. Portaluppi, D. E. Tenhouse, A. Lloyd, D. R. Eborn, S. Kacuba, and J. M. DeJarnette. 2007. Interventions after artificial insemination: Conception rates, pregnancy survival, and ovarian responses to gonadotropin-releasing hormone, human chorionic gonadotropin, and progesterone. J. Dairy Sci. 90:331-340. https://doi.org/10.3168/jds.S0022-0302(07)72634-6.

Taufa, V. K., K. L. Macmillan, A. M. Day, M. J. Ashcroft, and S. Morgan. 1998. Some effects of using progesterone and gonadotrophin releasing hormone on the reproductive performance of inseminated cows. Proc. N.Z. Soc. Anim. Prod. 58:92-94.

Tefera, M., S. Chaffaux, M. Thibier, and P. Humblot. 2001. A short note: lack of effect of post-AI hCG or GnRH treatment on embryonic mortality in dairy cattle. Livest. Prod. Sci. 71:277-281. https: //doi.org/10.1016/S0301-6226(01)00213-5.

Thatcher, W. W., A. Guzeloglu, A. Meikle, S. Kamimura, T. Bilby, A. A. Kowalski, L. Badinga, R. Pershing, J. Bartolome, and J. E. P. Santos. 2003. Regulation of embryo survival in cattle. Reproduction 61:253-266.

Van Cleeff, J., M. Drost, and W. W. Thatcher. 1991. Effects of postinsemination progesterone supplementation on fertility and subsequent estrous responses of dairy heifers. Theriogenology 36:795807. https://doi.org/10.1016/0093-691x(91)90345-e.
Vasconcelos, J. L. M., O. G. S. Filho, P. L. T. Justolin, P. Morelli, F. L. Aragon, and M. B. Veras. 2011. Effects of postbreeding gonadotropin treatments on conception rates of lactating dairy cows subjected to timed artificial insemination or embryo transfer in a tropical environment. J. Dairy Sci. 94:223-234. https://doi.org/10 .3168/jds.2010-3462.

Velázquez, J. E. C., C. A. E. Vázquez, R. U. Arvizu, and I. G. F. García. 2009. The effect of GnRH after insemination on progesterone concentrations and conception rates in repeat-breeding Holstein cows under heat stress conditions. Tec. Pecu. en Mex. 47:107-115.

Viechtbauer, W. 2010. Conducting meta-analyses in R with the metafor package. J. Stat. Softw. 36:1-48. https://doi.org/10.1103/ PhysRevB.91.121108.

Willard, S., S. Gandy, S. Bowers, and K. Graves. 2003. The effects of GnRH administration postinsemination on serum concentrations of progesterone and pregnancy rates in dairy cattle exposed to mild summer heat stress. Theriogenology 59:1799-1810. https:// doi.org/10.1016/s0093-691x(02)01232-3.

Wiltbank, M., H. Lopez, R. Sartori, S. Sangsritavong, and A. Gümen. 2006. Changes in reproductive physiology of lactating dairy cows due to elevated steroid metabolism. Theriogenology 65:17-29. https://doi.org/10.1016/j.theriogenology.2005.10.003.

Yan, L., R. Robinson, Z. Shi, and G. Mann. 2016. Efficacy of progesterone supplementation during early pregnancy in cows: A metaanalysis. Theriogenology 85:1390-1398. https://doi.org/10.1016/j .theriogenology.2015.12.027.

\section{ORCIDS}

M. Besbaci ๑ https://orcid.org/0000-0002-7934-6359

A. Abdelli $\odot$ https://orcid.org/0000-0001-9977-1232

D. Raboisson () https://orcid.org/0000-0003-1630-6218 